\title{
Immune cells in a case of postherpetic marginal trophic ulcer
}

\author{
KAREL GEBOES,' AHMED ABU EL-ASRAR, ${ }^{2}$ AND LUC MISSOTTEN 3
}

From the ${ }^{3}$ Department of Ophthalmology and 'Laboratory of Histochemistry and Cytochemistry, University Hospital St Rafaël, Leuven, Belgium; and the ${ }^{2}$ Department of Ophthalmology, Mansoura University Hospital, Egypt

SUMMARY The corneal surface was examined by means of replica histology, and the excised limbic conjunctiva was examined by routine histological and immunohistochemical methods with monoclonal antibodies directed against major histocompatibility class II antigens, lymphocyte subsets, Langerhans cells (HLA-DR, OKT -Leu3a, $\mathrm{OKT}_{8}, \mathrm{BA}_{1}, \mathrm{~B}_{1}$, and $\mathrm{OKT}_{6}$ ) and immunoglobulins $A, G, M$, and $D$. The findings were compared with those found in normal conjunctiva. No inflammatory cells were present in the replica of the corneal surface. An inflammatory infiltrate composed of B lymphocytes and null cells, in addition to T lymphocytes, Langerhans cells, and polymorphs, was present in the epithelium as well as in the stroma of the limbic conjunctiva. The composition of the infiltrate points towards the involvement of cell mediated immunity as well as humoral immunity. No immunoglobulins were bound to the conjunctival epithelium.

After prolonged epithelial geographic ulceration or stromal herpetic involvement the surrounding epithelium may fail to grow over the epithelial defect even in the absence of active viral or secondary bacterial infection.' This failure produces indolent epithelial ulcers which may run a particularly prolonged course and do not respond to therapy with topical antiviral drugs. The ulcers are usually complicated by profound corneal anaesthesia, and herpes simplex virus cannot be recovered from the cornea. ${ }^{2}$

The precise pathogenesis of the trophic corneal ulcer is still not clear. According to Kaufman, ${ }^{3}$ the failure of regrowth of the corneal epithelium is due to lack of epithelial basement membrane. Dohlman ${ }^{4}$ on the other hand believes that the basic problem may be a mitotic arrest and inhibition of cell sliding at the edge of the epithelial defect. This would be related to the ratio of cyclic AMP and cyclic GMP in the cells. It has been suggested that collagenases and proteases secreted by the diseased epithelium and stroma perpetuate the corneal damage and that the use of collagenase inhibitors may reduce the secondary inflammation. ${ }^{5}$ Moreover, idoxuridine is directly toxic to the epithelial cells and may be a contributing

Correspondence to Professor Dr L Missotten, Department of Ophthalmology, University Hospital St Rafaël, Kapucijnenvoer 7. B 3000 Leuven, Belgium. factor in the continued failure of the epithelium to cover the defects. ${ }^{\circ}$

Cell-mediated autoimmune phenomena have been reported in chronic herpetic keratitis with the demonstration of positive inhibition of leucocyte migration in response to corneal rather than viral antigens. ${ }^{7}$ On the other hand Mondino et al. ${ }^{8}$ suggested the involvement of humoral autoimmune phenomena in these cases owing to the finding of immunoglobulins and complement bound to the conjunctival epithelium adjacent to sites of active or previously active herpetic corneal disease. They detected circulating antibodies to the conjunctival epithelium in some cases and concluded that autoimmune phenomena may accompany or aggravate the extensive tissue destruction found in chronic herpetic keratitis.

The aim of this work is to study the cellular composition and distribution of the inflammatory infiltrate in a case of marginal postherpetic trophic ulcer in order to detect the role of immune mechanisms in the pathogenesis of trophic ulcers.

\section{Subjects and methods}

A 70-year-old female patient was followed up in the Department of Ophthalmology for a dendritic 


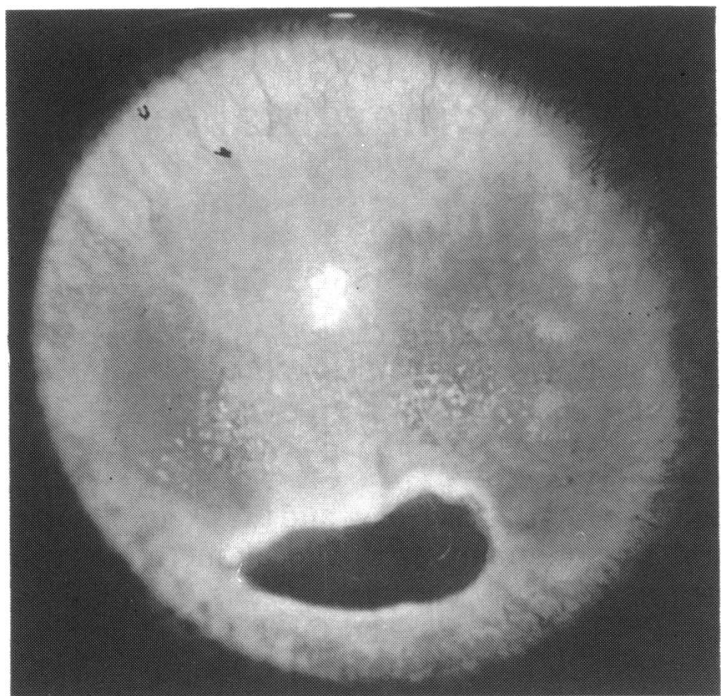

Fig. 1 Trophic ulcer located at the cornea periphery. The ulcer is stained with fluorescein and seen through a cobalt blue filter.

herpetic ulcer which progressed to marginal trophic ulcer (Fig. 1). She was treated with bromovinyl deoxyuridine (BVDU) and steroid eye drops in addition to an eyewash hourly with Ringer's lactate solution. This treatment remained unsuccessful.

A corneal replica was then made as described by Missotten and Maudgal. ${ }^{9}$ The technique of making a corneal replica is as follows: $(a)$ instill a local anaesthetic into the eye, $(b)$ keep the eye open with a speculum and dry the corneal surface by blowing air, (c) apply a thin layer of collodion amyl acetate solution, $3 \%-4 \% \mathrm{w} / \mathrm{v}$, on the corneal surface, $(d)$ dry the solution by blowing air for about 2 minutes, and peel off the dried membrane with a fine curved forceps. This membrane is the replica of the corneal surface, which can be mounted on glass slides for microscopic study. The limbic conjunctiva adjacent to the ulcer was excised, and the ulcer area was cleaned under local anaesthesia.

The excised limbic conjunctiva was divided into two parts. One part was fixed in Bouin's solution and embedded in paraffin. Semiserial sections were cut and stained with haematoxylin and eosin for routine histology. The other part was frozen in liquid nitrogen-cooled isopentane and used for immunohistochemical study. Serial cryostat sections $5 \mu \mathrm{m}$ thick were dried overnight at room temperature and subsequently fixed in absolute acetone for 10 minutes. An indirect immunoperoxidase procedure as described by Mason et al. ${ }^{110}$ was applied for the following monoclonal antibodies: $\mathrm{OKT}_{4}$, Leu 3a,
$\mathrm{OKT}_{8}, \mathrm{~B}_{1}, \mathrm{BA}_{1}, \mathrm{OKT}_{6}$, HLA-DR, and monoclonal antibodies directed against immunoglobulins $A, G$, $\mathrm{M}$, and $\mathrm{D}$.

The OK series of monoclonal antibodies were purchased from Ortho Pharmaceutical Co, Raritan,

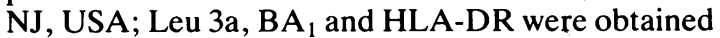
from Becton-Dickinson, Sunnyvale, CA, USA; $B_{1}$ was obtained from Coulter Electronic, Hialeah, FL, USA; monoclonal antibodies against immunoglobulins were obtained from Dakopatts $\mathrm{a} / \mathrm{s}$ Denmark.

$\mathrm{OKT}_{4}$ and Leu $3 \mathrm{a}$ define the helper/inducer $\mathrm{T}$ cell subset $^{1112}$ and were applied simultaneously. ${ }^{13} \mathrm{OKT}_{8}$ defines the suppressor/cytotoxic T-cell subset. ${ }^{1+} B_{1}$ reacts with all mature $B$ cells. ${ }^{15} \mathrm{BA}_{1}$ defines mature $B$ lymphocytes. ${ }^{16}$ HLA-DR is directed against major histocompatibility (MHC) class II antigens. ${ }^{17}$ And $\mathrm{OKT}_{6}$ defines cortical thymocytes, epidermal Langerhans cells, and interdigitating reticular cells. ${ }^{18} 14$

Following incubation with peroxidase-conjugated rabbit antimouse Ig (Dakopatts a/s, Copenhagen, Denmark) the reaction product was developed in 3-amino-9-ethylcarbazole (Aldrich Co., Beerse, Belgium) and $\mathrm{H}_{2} \mathrm{O}_{2}$ according to Graham et al. ${ }^{20}$ Sections were briefly counterstained with Mayer's haemalum and mounted in an aqueous medium.

A piece of normal conjunctiva obtained from a patient subjected to cataract surgery was studied in a similar way in order to correlate the findings observed in the case of trophic ulcer with those present in normal conjunctiva.

\section{Results}

\section{REPLICA HISTOLOGY}

The corneal replica was examined unstained by phase contrast and oblique illumination microscopy. The collodion membrane of the replica was then dissolved in acetone, and the cells removed with the replica were stained with Giemsa stain and examined by light microscopy.

The ulcer floor in the replica showed few necrosed cells, which were of irregular shape and arrangement. Some of them were fused. The ulcer margin was raised, forming a ridge sloping towards the floor (Fig. 2). It was formed of collections of degenerated cells, which were small, elongated, or rounded. These cells were partially fused and darkly stained. They had small, deformed dark nuclei. Many cells outside the ulcer area were swollen and some were fused. No inflammatory cells were seen in the surface layer.

NORMAL CONJUCTIVA

In the epithelium of the normal conjunctiva 


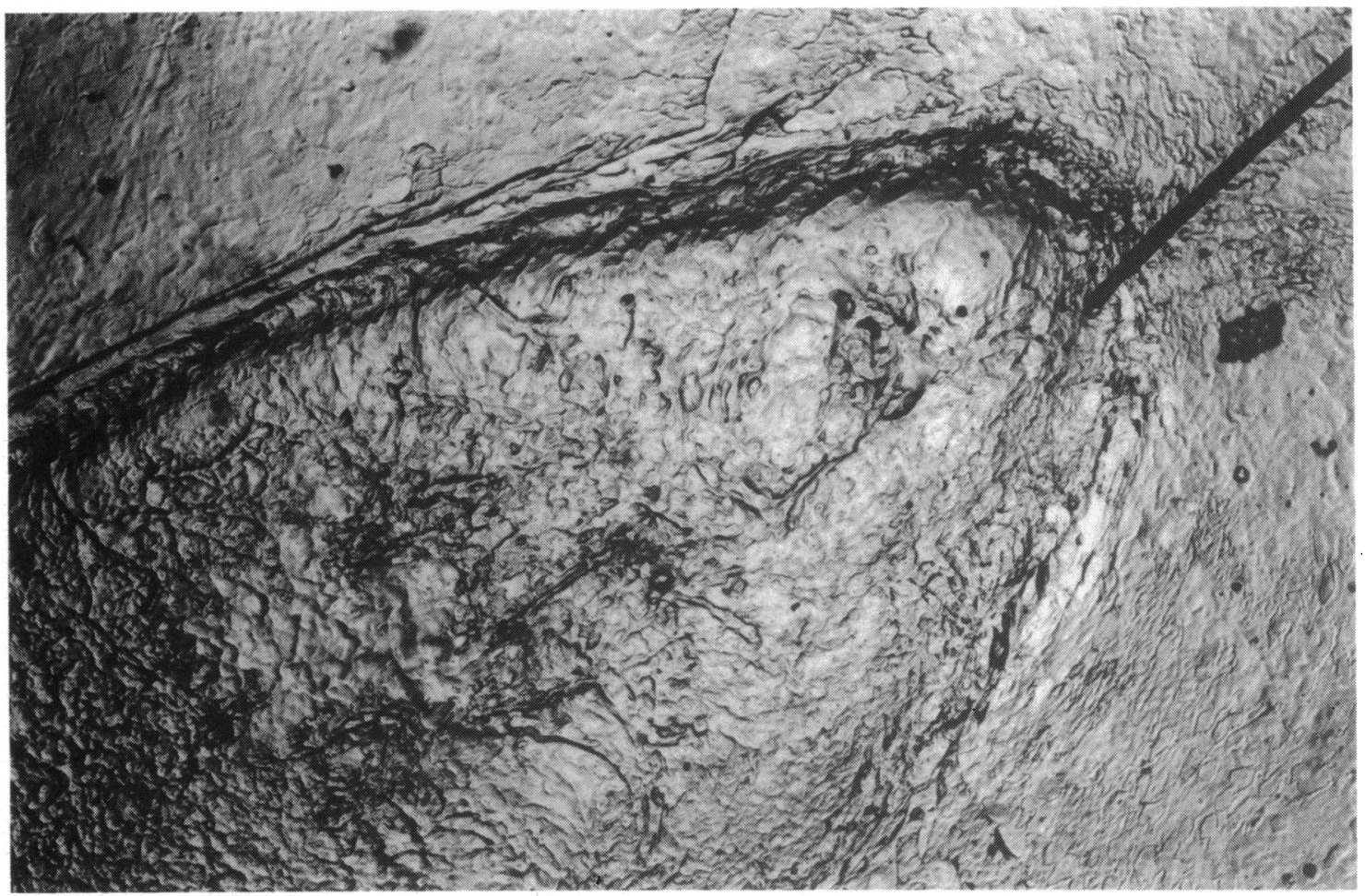

Fig. 2 Replica showing part of the trophic ulcer. Note that the ulcer margin is raised over the surface and is sloping towards the floor of the ulcer. Oblique illumination microscopy, $\times 175$.

occasional irregular HLA-DR positive cells were present between the epithelial cells. Irregular $\mathrm{OKT}_{6}{ }^{+}$ cells were less numerous, and $\mathrm{OKT}_{8}{ }^{+}$lymphocytes were rare. The substantia propria contained $\mathrm{OKT}_{4-}$ Leu $3 \mathrm{a}^{+}, \mathrm{OKT}_{8}{ }^{+}, \mathrm{BA}_{1}{ }^{+}$, and $\mathrm{B}_{1}{ }^{+}$lymphocytes. In addition scattered irregular $\mathrm{OKT}_{6}{ }^{+}$cells were found. The positive cells were present mainly in and around the blood vessels near the epithelium. Most of the round cells as well as the irregular cells were HLADR positive. The endothelial cells of the small blood vessels expressed HLA-DR. No immunoglobulins were expressed on the epithelial cells, but surface immunoglobulins, namely IgA, IgG, IgM, and IgD, were present on the surface membranes of some round cells in the stroma.

CONJUNCTIVAL BIOPSY OF THE TROPHIC ULCER Routine microscopy shows the presence of an increased inflammatory cell infiltrate in the stroma as well as in the epithelium. The infiltrate is composed of neutrophilic polymorphs and of mononuclear cells (Fig. 3). In the epithelium the inflammatory cells are few and scattered. In the stroma the infiltrate is more intense and more diffuse.

Immunohistochemistry reveals a positive staining

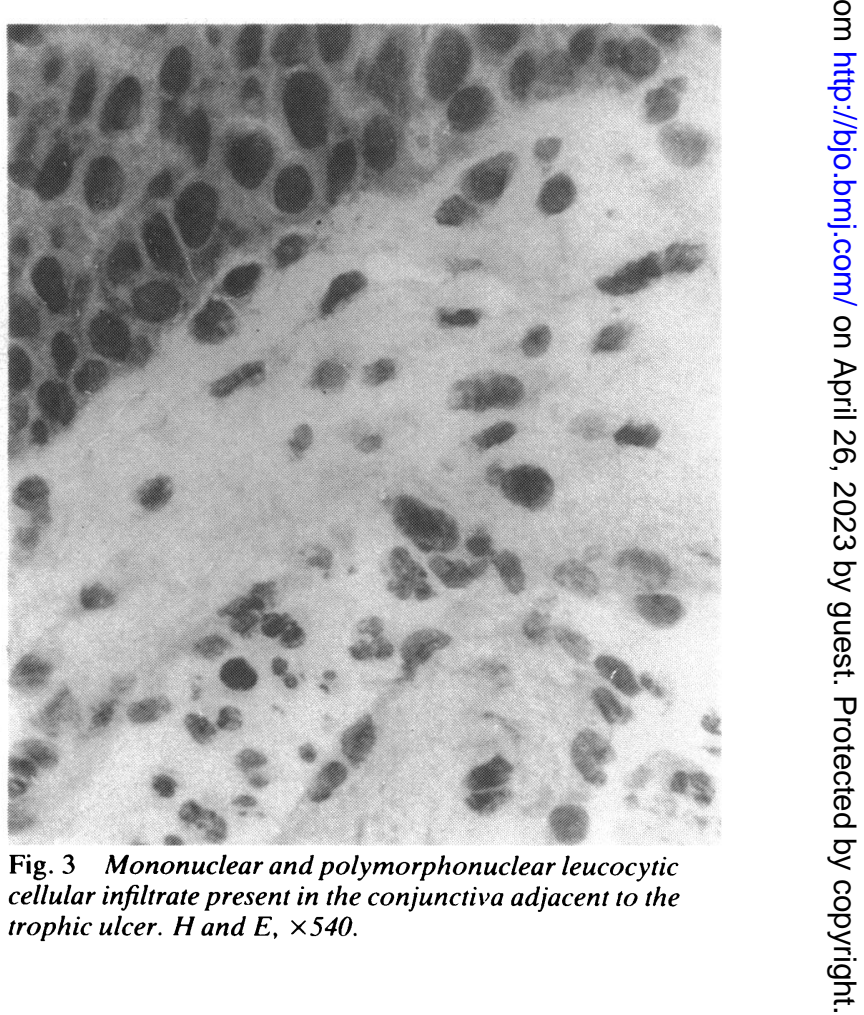


Fig. 4 Conjunctival biopsy of the trophic ulcer. A: the expression of MHC class II antigen on

interepithelial cells which are either Langerhans cells or lymphocytes is demonstrated. Immunoperoxidase, $\times 800$.

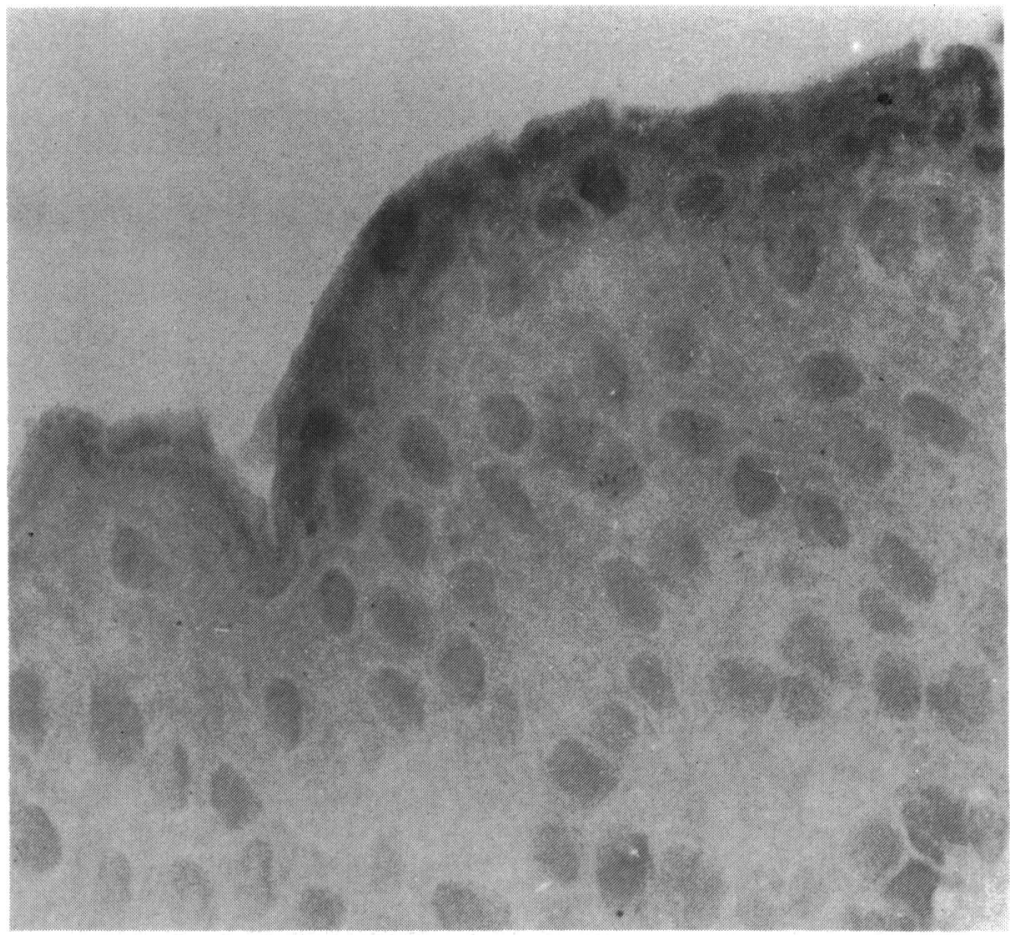

Fig. 4A

for HLA-DR on most of the inflammatory cells (Fig. 4A). The infiltrate is composed of $\mathrm{OKT}_{6}{ }^{+}, \mathrm{OKT}_{4}{ }^{-}$ Leu $3 \mathrm{a}^{+}, \mathrm{OKT}_{8}{ }^{+}, \mathrm{BA}_{1}{ }^{+}$, and $\mathrm{B}_{1}{ }^{+}$cells (Fig. 4B). They are present in small numbers within the epithelium and in higher numbers in the substantia propria (Fig. 5). In addition many mononuclear cells not expressing any immunoreactivity with the monoclonal antibodies used in this study are observed. The
Fig. 4 B: $B_{1}{ }^{+}$, B lymphocytes in between the epithelial cells. Immunoperoxidase, $\times 800$.

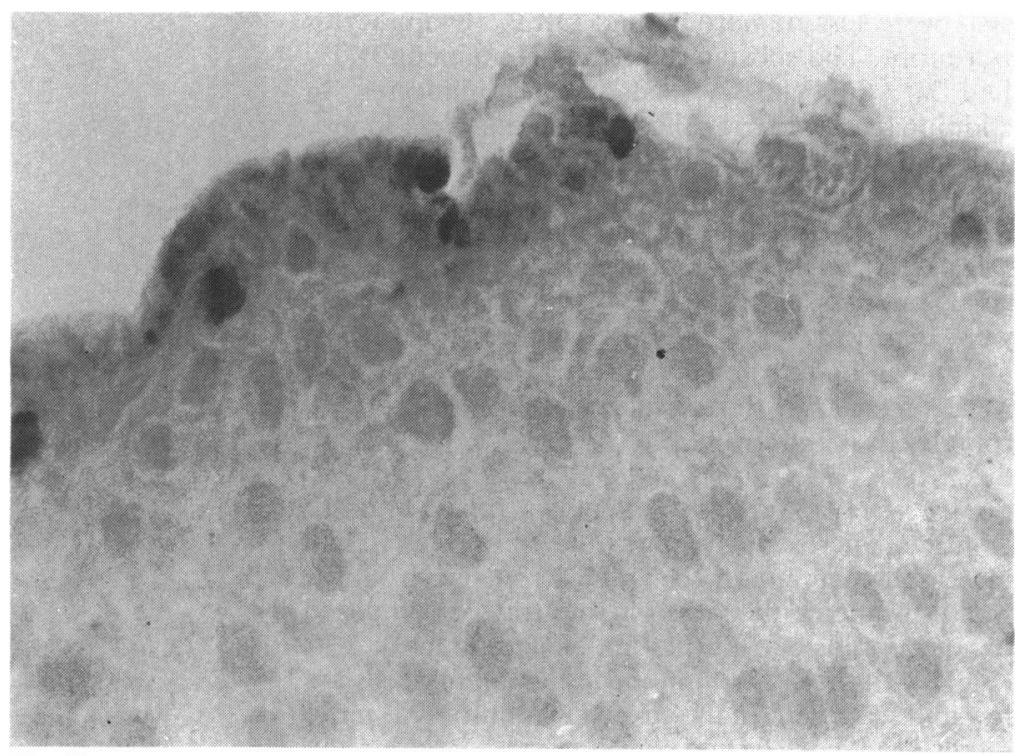

Fig.4B 


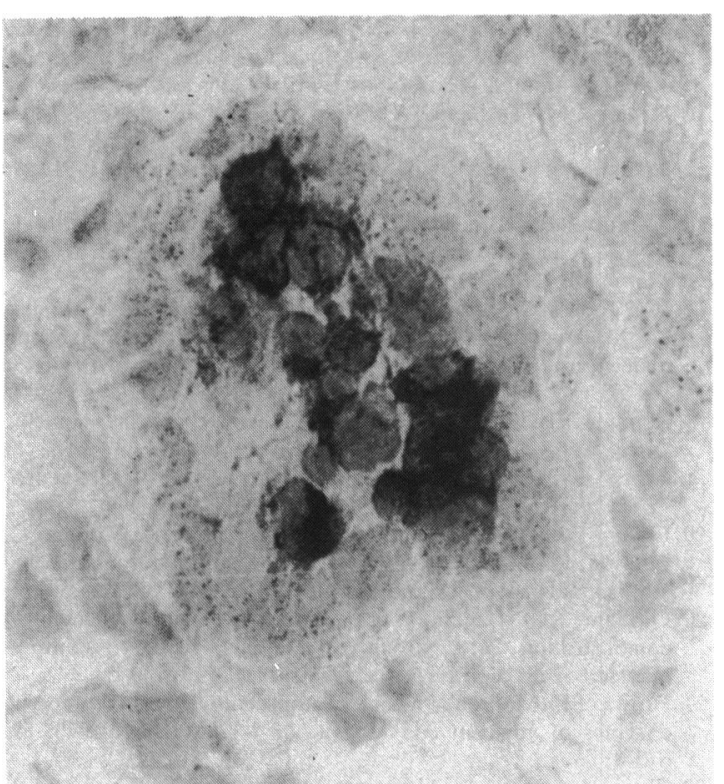

Fig. $5 \mathrm{~B}_{1}{ }^{+}, \mathrm{B}$ lymphocytes present in the stroma of the conjunctiva adjacent to the trophic ulcer. Immunoperoxidase, $\times 800$.

conjunctival epithelium is not expressing immunoglobulins. Surface immunoglobulins, namely, IgA, IgG, IgM, and IgD, are found bound to the surface membranes of some mononuclear cells in the epithelium as well as in the substantia propria.

\section{Discussion}

From the replica histology it appears that there are no inflammatory cells in the surface layer of the trophic herpetic ulcer.

Routine microscopy of the conjunctiva adjacent to the ulcer shows an increased inflammatory infiltrate composed of mononuclear cells and polymorphonuclear leucocytes. The infiltrate is present in the epithelium and in the underlying stroma. Similar findings were noted in the conjunctiva adjacent to Mooren's ulcer, ${ }^{2122}$ and several studies suggested an autoimmune basis for the pathogenesis of this ulcer. ${ }^{212324}$

Immunohistochemistry reveals many inflammatory cells expressing the major histocompatibility class II antigens. Class II histocompatibility antigens are known to be present on many types of cells involved in immune responses, including B cells, activated $\mathrm{T}$ cells, some macrophages, and interdigitating cells. Their presence on these cells is associated with antigen recognition and presentation to $T$ cells and the initiation of specific $B$ and $T$ cell responses. ${ }^{25} 26$
In comparison with normal conjunctiva, the number of $\mathrm{OKT}_{6}{ }^{+}$, Langerhans cells, and of $\mathrm{OKT}_{8}{ }^{+}$, suppressor/cytotoxic $\mathrm{T}$ lymphocytes in the conjunctival epithelium near the trophic ulcer is increased. In addition $\mathrm{OKT}_{4}$-Leu $3 \mathrm{a}^{+}$, helper/inducer $\mathrm{T}$ lymphocytes and $\mathrm{BA}_{1}^{+}, \mathrm{B}_{1}^{+}, \mathrm{B}$ lymphocytes are present in the epithelium. In the substantia propria the inflammatory cell infiltrate is even more intense than in the epithelium. It is composed of a mixture of $\mathrm{OKT}_{6}{ }^{+}$, $\mathrm{OKT}_{4}$-Leu $3 \mathrm{a}^{+}, \mathrm{OKT}_{8}{ }^{+}, \mathrm{B}_{1}{ }^{+}$, and $\mathrm{BA}_{1}{ }^{+}$cells. These cells are also more numerous than in normal conjunctiva.

The most striking observation is the presence of numerous round cells that are not stained with the monoclonal antibodies used and lack specific identifying surface markers for either T or B lymphocytes. Accordingly we suggest that many mononuclear cells present in the infiltrate are null cells. Because of their granular microscopic aspect some of these null cells are probably natural killer cells. In man natural killer cells have the appearance of large lymphocytes with an idented nucleus and prominent granules. ${ }^{27}$ It has been shown experimentally that natural killer cells may have a role in limiting herpes simplex virus infections. ${ }^{2 k}$

No immunoglobulins are expressed on the conjunctival epithelial cells near the trophic ulcer. On the other hand Mondino et al. ${ }^{8}$ detected immunoglobulins bound to the conjunctival epithelium in seven out of 11 patients with chronic herpetic keratitis.

Our findings indicate that an inflammatory reaction is present in the conjunctiva near the trophic ulcer. The inflammatory reaction is predominantly a reaction of mononuclear cells. The infiltrate is a mixture of accessory cells (Langerhans cells), various subtypes of $\mathrm{T}$ lymphocytes, B lymphocytes, and null cells. The presence of both $T$ and $B$ lymphocytes suggests an underlying immunological mechanism.

There are at least six antigenic glycoproteins at the surface of the virion that also appear at the surface of the infected cell. ${ }^{29}$ Immune mechanisms can therefore interact not only with the virus but also with cells infected by the virus. This reaction is possible even in the absence of the replicating virus. We suggest that HSV-induced antigenic changes of the surface membranes of the epithelial cells stimulate immune reactions that lead to the development of a persistent ulceration.

The presence of Langerhans cells and $\mathrm{T}$ lymphocytes (helper/inducer and suppressor/cytotoxic subsets) as well as of B lymphocytes indicates that the underlying immune mechanisms are complex and that both cell mediated immunity and humoral immunity are involved. The presence of numerous null cells is more difficult to explain. It might be 
related to local steroid therapy, which is known to influence the immune response and the expression of antigens. But some of the unstained cells are probably natural killer cells and could be directly involved in the development of the ulcer.

\section{References}

1 Binder PS. Herpes simplex keratitis. Surv Ophthalmol 1976; 21: 313-30.

2 Dawson CR, Togni B. Herpes simplex eye infections: clinical manifestations, pathogenesis and management. Surv Ophthalmol 1976; 21: 121-35.

3 Kaufman HE. Epithelial erosion syndrome: metaherpetic keratitis. Am J Ophthalmol 1964; 57: 983-7.

4 Dohlman $\mathrm{CH}$. The corneal epithelium in disease. In: $X X I I t$ concilium ophthalmologicum. Amsterdam: Excerpta medica. 1979: 265-8.

5 Berman M, Kerza-Kwiatechi AP, Davison PF. Characterization of human corneal collagenase. Exp Eye Res 1973; 15: 367-73.

6 Thygeson P, Sexton R, Corwin M. Observations on the IDUR therapy of herpetic keratitis. Trans Pacific Coast Oto-ophthalmol Soc 1963; 44: 81-4

7 Shore B, Leopold IH, Henley WL. Cellular immunity in chronic ophthalmic disorders: II. Leucocyte migration inhibition in diseases of the cornea. Am J Ophthalmol 1972; 73: 62-76.

8 Mondino BJ, Brown SI, Rabin BS. Autoimmune phenomena of the external eye. Ophthalmology 1978; 85: 801-17.

9 Missotten L, Maudgal PC. The replica technique used to study the superficial corneal epithelium in vivo. Am J Ophthalmol 1977; 84: 104-11.

10 Mason DY, Naiem M, Abdulaziz Z, Nash JRG, Gatter KC, Stein $\mathrm{H}$. Immunohistochemical labelling of cryostat sections with monoclonal antibody. In: McMichael AJ, Fabre JW, eds. Monoclonal antibodies in clinical medicine. London: Academic Press, 1982: 632-5.

11 Reinherz EL, Kung PC, Goldstein G, Schlossman SF. Further characterization of the human inducer $T$ cell subset defined by a monoclonal antibody. J Immunol 1979; 123: 2894-6.

12 Ledbetter JA, Evans RL, Lipinski M, Cunningham-Rundles C, Good RA, Herzenberg LA. Evolutionary conservation of surface molecules that distinguish $\mathrm{T}$ lymphocyte helper/inducer and cytotoxic/suppressor subpopulations in mouse and man. $J$ Exp Med 1981; 153: 310-23.

13 Van den Oord JJ, de Wolf-Peeters C, Vanstapel MJ, Desmet VJ. Improved visualization of helper/inducer T-cells by the simultaneous application of two, non-crossblocking monoclonal antibodies. Stain Technol 1985; 60: 45-9.

14 Reinherz EL, Kung PC, Goldstein G, Schlossman SF. A monoclonal antibody reactive with the human cytotoxic/ suppressor T-cell subset previously defined by a heteroantiserum termed $\mathrm{TH}_{2}$. J Immunol 1980; 124: 1301-7.

15 Nadler LM. Stashenko P. Ritz J, Hardy R, Pesando JM, Schlossman SF. A unique cell surface molecule identifying lymphoid malignancies of B cell origin. J Clin Invest 1981; 67: $134-40$.

16 Abramson CS. Kersey JH, Le Bien TW. A monoclonal antibody $\left(\mathrm{BA}_{1}\right)$, reactive with cells of human $\mathrm{B}$ lymphocyte lineage. J Immunol 1981; 126: 83-8.

17 Van der Valk P, Van der Loo EM, Jansen J, Daha MR, Meijer CJLM. Analysis of lymphoid and dendritic cells in human lymph node, tonsil and spleen. Virchows Arch (Cell Pathol) 1984; 45: 169-85.

18 Reinherz EL. Kung PC. Goldstein G, Levey RH, Schlossman SF. Discrete stages of human intrathymic differentiation: analysis of normal thymocyte and leukaemic lymphoblasts of T-cell lineage. Proc Natl Acad Sci USA 1980; 77: 1588-92.

19 Fithian E, Kung PC, Goldstein G, Rubenfeld M, Fenoglio C, Edelson R. Reactivity of Langerhans cells with hybridoma monoclonal antibody. Proc Natl Acad Sci USA 1981; 78: 2541-4.

20 Graham RC, Lundholm U, Karnovsky MJ. Cytochemical demonstration of peroxidase activity with 3-amino-9ethylcarbazole. J Histochem Cytochem 1965; 13: 150-2.

21 Brown SI. Mooren's ulcer. Histopathology and proteolytic enzymes of adjacent conjunctiva. Br J Ophthalmol 1975; 59: 670-4.

22 Foster CS, Kenyon KR, Greiner J, Greineder DK, Friedland B, Allansmith MR. Immunopathology of Mooren's ulcer. Am J Ophthalmol 1979: 88: 149-58.

23 Brown SI. What is Mooren's ulcer? Trans Ophthalmol Soc UK 1978: 98: 390-2.

24 Murray PI, Rahi AHS. Pathogenesis of Mooren's ulcer: some new concepts. Br J Ophthalmol 1984; 68: 182-7.

25 Unanue ER. The regulatory role of macrophages in antigenic stimulation. Part two: symbiotic relationship between lymphocytes and macrophages. Adv Immunol 1981; 31: 1-136.

26 Thoresby E, Berle E, Nousiainen H. HLA-D region molecules restrict proliferative $\mathrm{T}$ cell responses to antigen. Immunol Rev 1982; 66: 39-56.

27 Saksela E, Timonen T, Ranki A, Hayry P. Morphological and functional characterization of isolated effector cells responsible for human natural Killer activity to fetal fibroblasts and to cultured cell line targets. Immunol Rev 1979; 44: 71-123.

28 Habu S, Akamatsu K, Tamaoki N, Okumura K. In vivo significance of NK cell on resistance against virus (HSV-1) infections in mice. J Immunol 1984; 133: 2743-7.

29 Wildy P, Gell PGH. The host response to herpes simplex virus. Br Med Bull 1985; 41: 86-91.

Accepted for publication 25 March 1988. 